\title{
Miroslav Kazík
}

Univerzita sv. Cyrila a Metoda, Trnava

\section{Toponymá v živých osobných menách}

\section{Úvod}

Živé osobné meno je v slovenskej onomastike chápané ako neúradné pomenovanie osoby, ktoré je zložené z jedného alebo viacerých funkčných členov, ktorými môžu byt' krstné (rodné) meno, priezvisko, rodinné meno, individuálna charakteristika, meno domu a apelatívny člen. Toponymá v živých menách môžu byt' východiskom pre vytvorenie obyvatel'ského mena, ktoré je čast'ou živého mena, ale aj samotné toponymá môžu vstupovat' do živých mien, a to ako funkčný člen individuálna charakteristika podl'a pôvodu a bydliska (CHp) a ako funkčný člen meno domu (MD). Náš materiál živých mien pochádza z terénneho výskumu v kopaničiarskej oblasti Starej Turej.

V goralskej oblasti na Spiši tvorili živé mená z miestnych názvov 10,22\% z celkového počtu živých mien [Kriššáková 1976].

\section{Individuálna charakteristika podl’a pôvodu a bydliska}

Individuálna charakteristika sa vyznačuje antroponymickými sémantickými príznakmi [+ jednotlivec bez vzt’ahu k iným (príbuzným/nepríbuzným) osobám] a [- dedičnost']. Týmito príznakmi sa vydel'ujú individuálna charakteristika i rodné (krstné) meno oproti ostatným členom ako individuálne, nededičné funkčné členy. Individuálna charakteristika podobne ako živé rodinné meno a meno domu je ustálená užším spoločenským úzom. Pri výbere a tvorení individuálnej charakteristiky sa môžu uplatňovat' hodnotiace postoje pomenúvatel'ov, pokial' ide o expresívnost' [+ - konotatívnost'] a pokial' ide o tzv. spoločenskú príznakovost' [+ - spoločenské zaradenie a hodnotenie] [Blanár, Matejčík 1978: 29]. Individuálna charakteristika môže byt' v niektorých prípadoch dedičná, má vzt'ah $\mathrm{k}$ iným, zväčša príbuzným osobám. Nezmenený názov toponyma, resp. miesto bydliska pri $\mathrm{CH}^{\mathrm{p}}$ vždy vyžaduje iné funkčné členy: napr. v Papradi Vjera Mednanská 
s Koščálech dolini, Letanedz Oproti šenku na Papradi, Žofa Zemanová z Jazvín/ z Jazvín Žofa Zemanová, Bunov sin Spod dubal Branov Spod duba Babušákéch sin, Mišova Beta Borsukéch zo Salaša, Beta Hluchá z Mlina, z Bjelčikech dolini Ruda Kubánka manželka, Jaro z Raškového, Pražjenka s Černochovho Vrchu, Anna Z meskej, Lida s Polomi/Lida Durcéch s Polomi, Dušan Mednanskí z Močára, Milka Dole Pod opchodom, Bjelčička Jara zo Spodnej ulici, po Jarovi Kiškovi $Z$ dolnej ulici žena, Maroš Bjesik Z bitovki, Rudo Vichlopnéch Ze stanici.

Podl'a I. Valentovej [2009: 76], ktorá realizovala výskum živých mien v hornonitrianskej oblasti, CHp býva často motivovaná: 1. názvom dediny, z ktorej pochádza pomenovaná osoba alebo iný rodinný príslušník, ktorý sa do obce priženil či žena vydala, 2. podl'a delenia domu na prednú a zadnú čast', 3. názvom budovy, resp. druh budovy, z ktorej osoba pochádzala, 4. názvom časti dediny, miesta $\mathrm{v}$ dedine, toponymum, či už osoba $\mathrm{z}$ danej oblasti pochádza alebo $\mathrm{v}$ nej priamo býva, 5. obyvatel'ským živým menom. CHp sa najčastejšie tvorí tak, že z názvu miesta pôvodu alebo bydliska sa vytvorí desubstantívum alebo pomocou predložky [Valentová 2009: 77].

Individuálna charakteristika podl'a pôvodu a bydliska môže byt' na kopaniciach Starej Turej vyjadrená:

a) antroponymom, ktoré do živého mena často vstupuje ako obyvatel'ské meno,

- býva motivované ojkonymom (Súča $>$ Súčan, Važec $>$ Vaščanka),

- názvom časti mesta alebo obce (Raškové, Na Raškovom >Raškovan; Gašová > Gašák, Gašovár, Gašovárka, Šimún Gašovár, Jaro Gašovár; Trnová > Trnovská, Kačka Trnovská $\left./ \underline{\mathrm{K}}+\mathrm{CH}^{\mathrm{p}} /\right)$,

ale občas i ako (obyvatel'ská) prezývka (prezývkové obyvatel'ské meno)

- motivovaná hydronymom (Zavažan - býva za Váhom),

individuálna prezývka

- motivovaná ojkonymom (Pražanda - je z Prahy, antropoformant -anda, Prašská holka, zat Prašskej holki),

b) etnonymom, ktoré vychádza z názvu štátu, živé meno je motivované názvom štátu (pracuje v Nemecku - Nemec, sestru má v Taliansku - Talianka, býva pri Mad'arsku - Mad'arka),

c) predložkou a toponymom

- názvom obce alebo osady (Danka z Jablonki /pochádza z Jablonky/, s Černochovho Vrchu, s Koščáléch dolini, Dana s Koščálech dolini (podl'a pôvodu) /K $+\mathrm{CH}^{\mathrm{p}} /$, na Papradi, f Koščáléch doline, Rudo Búzik u Samkov, Áronkina sestra s Paprade, Tóno z Dolini /je z Drgoňovej doliny/, Milka z Mijavského /pochádza $\mathrm{z}$ myjavských kopaníc/, Anka Gregorka z Mijavského $/ \underline{\mathrm{K}}+\mathrm{RM}_{3}=\mathrm{P}+\mathrm{CH}^{\mathrm{p}} /$, Betka Pribišová z Mijavského $/ \underline{\mathrm{K}}+\mathrm{P}_{3}=\mathrm{RMD}+\mathrm{CH}^{\mathrm{p}} /$, Milka z Hlavini Poštárova (pochádza z Hlaviny) $/ \mathrm{K}+\mathrm{CH}^{\mathrm{p}}+\mathrm{CH}_{3}^{\mathrm{z}}$, Šimún z Hlavini $\left(<\mathrm{K}>+\mathrm{CH}^{\mathrm{p}}\right)$, Jano Gregor $z$ Hlavini $\left(\underline{\mathrm{K}}+\mathrm{P}=\mathrm{RMD}+\mathrm{CH}^{\mathrm{p}}\right)$, Jano Hluchi z Nárca spod Ježovej $(\underline{\mathrm{K}}+\mathrm{P}=\mathrm{MD}$ $\left.+\mathrm{CH}^{\mathrm{p}}+\mathrm{CH}^{\mathrm{p}} / \mathrm{MD}\right)$, Betka Pribiška (z Brestovca Šustréch) $/ \underline{\mathrm{K}}+\mathrm{RM}_{3}=\mathrm{P}+{ }^{0}\left(\mathrm{CH}^{\mathrm{p}}\right.$ $\left.+\mathrm{RM}_{1}\right) / /$ pochádza z Brestovca/, z Jazvín, Malková z Rudníka, Letanedz Oproti 
šenku na Papradi $/ \mathrm{P}=\mathrm{RMD}+\mathrm{CH}^{\mathrm{p}}+\mathrm{CH}^{\mathrm{p}} /$, Zdenko Malek na Papradi Pri šenku $\left./(\mathrm{K}+\mathrm{P}=\mathrm{RMD}: \mathrm{MD})+\mathrm{CH}^{\mathrm{p}}+\mathrm{CH}^{\mathrm{p}} /\right)$,

- názvom časti osady alebo chotárnym názvom ( $\mathrm{z}$ Močára, na Močári, s Kimlového, na Salaši, Anna z Meskej /podl'a parcely/, Nemcová ze Žarlákového Mikulcéch Martina, Mikulcéch Božena ze Žarlákového, Gusto Pod horu, Gusto Nemcéch Pod horu, Gusto Nemec Pod horu, Lubo Gurášní na Papierni / $\underline{\mathrm{K}}+\mathrm{CH}^{\mathrm{v}}{ }_{1}$ $+\mathrm{CH} /-\mathrm{MD}:<\mathrm{MD}>/$, Áčová pod Jazvinami $/ \mathrm{CH}^{\mathrm{v}}{ }_{3}+\mathrm{CH}^{\mathrm{p} /} / \mathrm{MD} /$, mladá Pribiška spod Ježovej /A - $\mathrm{RM}_{3}=\mathrm{P}+\mathrm{CH}^{\mathrm{p}} /$, Miro Guráš spod Ježovej $\left(\underline{\mathrm{K}}+\mathrm{CH}_{1}^{\mathrm{v}}=\mathrm{CH}^{\mathrm{v}}+\right.$ $\left.\mathrm{CH}^{\mathrm{p}}\right)$, tetka Dúbravčikéch Za potokom $/ \mathrm{A}-{ }^{*} \mathrm{RM}_{3}=\mathrm{P}+\mathrm{CH}^{\mathrm{p}} /$, Milka Za potokom Dúbravčíéch $/ \underline{\mathrm{K}}+\mathrm{CH}^{\mathrm{p}}+* \mathrm{RM}_{3}=\mathrm{P} /$, Anička z Dúbravi $/ \underline{\mathrm{K}}+\mathrm{CH}^{\mathrm{p}} /$, Durcova s Pola, Bjelčiková Anna Spod duba Babušáčka $/ \mathrm{P}_{3}=<\mathrm{RM}>+\mathrm{K}+\mathrm{CH}^{\mathrm{p}} / \mathrm{MD}+$ $\mathrm{RM}_{[3]}$, Jaro z Raškového $/ \underline{\mathrm{K}}+\mathrm{CH}^{\mathrm{p} /}<\mathrm{RMD}>/$ ),

d) predložkou a živým urbanonymom (zo Spodnej ulici, z Dolnej ulici),

e) predložkou a apelatívom (názvom budovy) (Nad hasičárnu, Nad zbrojnicou, Z bitovki, Oproti šenku, Pri šenku, Pri opchode, Pri zbrojnici, Pod opchodom, Pot školu).

Aj vyjadrenia predložkou a apelatívom možno v lokálnom priestore považovat' za živé urbanonymá, teda toponymá, ktoré plnia identifikačnú, diferenciačnú a lokalizačnú funkciu. Pomocou predložky a apelatíva sa tak presne určuje miesto.

Individuálne charakteristiky podl'a pôvodu a bydliska sú v nasledujúcich tvaroch:

a) v nominatíve singuláru substantíva alebo adjektíva,

b) ako predložkové spojenia sú tiež v genitíve singuláru substantíva mužského rodu (neživotné) (z Mlina, Spod duba, s Černochovho Vrchu), ženského rodu (z Meskej, zo Spodnej ulici, z Dolnej ulici, s Koščáléch dolini, z Drgonéch dolini, z Durcéch dolini), stredného rodu (z Raškového) a plurálu (ženského rodu - z Jazvin),

c) v lokáli singuláru substantíva mužského rodu (životné - pri Černákovi, neživotné - Pri opchode), v lokáli singuláru substantíva, ktorý sa tu viaže s predložkou na,

d) v inštrumentáli singuláru substantíva mužského rodu (neživotné) (Pod opchodom), ženského rodu (Pot školu, Nad zbrojnicou).

Pri CHp sa využívajú predložky z, (zo), na, v, nad, pri, oproti, spod, pod.

Nárečové prvky sú vo výslovnosti - spoluhlásková skupina št' sa nahrádza skupinou šč (s Koščáléch dolini). Genitív singuláru substantíva ženského rodu vzoru ulica sa končí na -i: $z$ ulici. Názov lokality Koščáléch dolina je vytvorený nárečovým sufixom kolektívneho posesíva -éch: s Koščáléch dolini. Používajú sa tvary Durcéch dolina, Drgonéch dolina (z Durcéch dolini, z Drgonéch dolini) miesto úradných názvov Durcova dolina, Drgoňova dolina. Miesto názvu Durcova dolina sa stretávame aj s eliptickým Dolina (sin Janka Zemana z Dolini). Okrem náležitého tvaru $s$ Černochovho Vrchu sme zaregistrovali tvar $s$ Černochového Vrchu, ktorý je genitívom singuláru vlastnostných a nie privlastňovacích adjektív. Názov osady sa nazýva Černochov Vrch a nie „Černochový Vrch“. 


\section{Meno (do) domu}

Mená (do) domu podl'a V. Blanára [1996: 110] tvoria prechod medzi antroponymami a toponymami, presnejšie medzi anojkonymami a živými osobnými menami (do Karola Kostolníka, ku Mišovi Tŕnikovi, u Števa Paukou, od Žňavov). „Podstatný rozdiel medzi týmito dvoma propriálnymi vrstvami spočíva $\mathrm{v}$ tom, že anojkonymá sa viažu na pevný bod v teréne, kým podstatné obsahové prvky osobných mien vyplývajú z ich sociálnej zakotvenosti““ [Blanár 1996: 110]. Meno (do) domu funguje ako samostatné živé meno, ale môže byt' aj súčast'ou živého osobného mena ako jeho funkčný člen. Vyznačuje sa príznakmi [+ dedičnost'], [+ príbuzenský vzt’ah k rodine ako celku], [+ užší spoločenský úzus] a špecifickým sémantickým príznakom [+ lokalizačný vzt’ah], ktorý signalizuje, že osoba je cez meno domu spätá so svojím bydliskom [Blanár, Matejčík 1978: 30]. Pri funkčnom člene meno domu rozlišujeme: a) meno domu s antropobázou priezviska, b) meno domu s antropobázou mena rodiny, c) mena domu podl'a polohy, d) meno domu, ktoré nie je zhodné s antropobázou priezviska, ani s antropobázou mena rodiny a nevyjadruje ani polohu.

E. Krasnovská [1975: 43] delí mená do domu na mená utvorené 1. z mena dnešného majitel’a a) z jeho priezviska, b) z jeho dedičného živého rodinného mena, 2. z mena bývalého majitel’a s iným osobným menom, na ktorého si dnešná generácia častejšie nepamätá, 3. meno domu sa vzt’ahuje na polohu, miesto, kde dom leží. Sem patria aj bližšie určenia častí dvora, príp. domu. I. Valentová [2009: 103] uvádza živé osobné mená Darina Lánouská, Marka Lánouská, kde meno domu má predložkový tvar na Láni a vzniklo z chotárneho názvu Lány, na ktorom postavili dom a celé gazdovstvo. FČ Lánouská hodnotí ako CHp. Pre hornonitriansku oblast' uvádza typy mena domu s predložkou od + subst. -ou (Ol'ga ot Cingáčou) a s predložkou $u$ (Učit'el’ u Ďurčou). Mená domov sú najčastejšie motivované priezviskom otca, resp. rodným priezviskom vydatej ženy, individuálnou charakteristikou podl'a zamestnania a rodným (krstným) menom.

Meno domu v staroturianskej oblasti môže byt' vyjadrené:

a) predložkou a antroponymom (antropobáza tohto mena domu pochádza z priezviska, rodinného mena, možno i charakteristiky predchádzajúcich majitel'ov či obyvatel'ov domu, resp. skupiny domov) (Filúz ot Kalúsov /P + MD/, Brano Stachéch ot Kalúsov $/ \underline{\mathrm{K}}+<\mathrm{RM}>=\mathrm{P}+\mathrm{MD} /$, Ivan Sallon na Kurpašovém $/ \mathrm{K}+<\mathrm{P}>$ $=\mathrm{RMD}+\mathrm{MD} /$, Dušan Mednanski od Hutcov $/ \mathrm{K}+<\mathrm{P}>=\mathrm{RMD}+\mathrm{MD} /$, Vrkočova Palova ot Klimáčkou $/(\mathrm{P}=\mathrm{RMD}+\underline{\mathrm{K}})_{3}+\mathrm{MD} /$, Patajko u Strelcov $/ \mathrm{RM}_{33}+\mathrm{MD} /$,

b) predložkou a antroponymom (antropobáza mena domu je zhodná s antropobázou rodinného mena (ujco Palo Bjesikéch ot Strelcov /A - $\underline{\mathrm{K}}+\mathrm{RM}=\mathrm{P}+\mathrm{MD}$ $=<\mathrm{RM}>/$,

c) názvom menšej osady, ktorej názov je tvorený predložkou $u$ a priezviskom časti obyvatel'ov v pluráli (Vlado Pilek u Čubanákov / $\underline{\mathrm{K}}+\mathrm{P}=\mathrm{RMD}+\mathrm{MD} /$, 
U Čubanákov je pomenovanie skupiny domov, menšej osady, v ktorej dodnes žijú i obyvatelia s priezviskom Čubanák), Milka Bušéch U Mikulcov $/ \underline{\mathrm{K}}+\mathrm{RM}_{1}=$ $<\mathrm{MD}>+\left(\mathrm{MD}_{1 / 2}=\mathrm{P}\right)=\mathrm{CH}^{\mathrm{p}} /$, U Mikulcov je meno domu, $\mathrm{v}$ ktorom býva pomenovaná. Bol to pôvodne dom otca. Meno domu obsahuje antropolexému priezviska. U Mikulcov je zároveň názov osady, ktorý je motivovaný priezviskom obyvatel'ov, názov osady: Jazviny, čast' U Mikulcov; Všetulka u Vankov $/ \mathrm{RM}_{3}=\mathrm{P}+\mathrm{MD} /$, Všetulová u Vankov, Všetulová od Vankov $/ \mathrm{P}_{3}=\mathrm{RMD}+\mathrm{MD} /$, Anna Všetulová Pilková (U Vankov) $/ \mathrm{K}+\mathrm{P}_{3}=\mathrm{RMD}+\mathrm{P}_{1}+{ }^{0} \mathrm{MD} /$, U Vankov je názov menšej osady, ktorý vznikol z priezviska jej niekdajších obyvatel'ov),

d) predložkou $z, n a$, spod alebo spopod a názvom menšej osady, chotárnym názvom alebo apelatívom (Dušan z Brezovki $/ \mathrm{K}+\mathrm{MD}=\mathrm{CH}^{\mathrm{p}} /$, Marijan z Járkov $/<\mathrm{K}>+\mathrm{MD}=\mathrm{CH}^{\mathrm{p}} /$, Vlasta Z brehu $/ \mathrm{K}+\mathrm{MD}=\mathrm{CH}^{\mathrm{p}} /$, Anča z Brezovki $/ \underline{\mathrm{K}}+$ $\mathrm{MD}=\mathrm{CH}^{\mathrm{p}} /$, Beta z Brezovki $/ \underline{\mathrm{K}}+\mathrm{MD}=\mathrm{CH}^{\mathrm{p}} /$, Janka Z brehu $/ \mathrm{K}+\mathrm{MD}=\mathrm{CH} /$, Dušan z Dúbravi $/ \mathrm{K}+\mathrm{MD}=\mathrm{CH}^{\mathrm{p}} /$, Murár z Gašovej $/ \mathrm{CH}^{\mathrm{z}}+\mathrm{MD}=\mathrm{CH}^{\mathrm{p}} /$, Jano Inteligent s Trnovej $/ \underline{\mathrm{K}}+\mathrm{CH}^{\mathrm{v}} / \mathrm{MD}+\mathrm{MD}=\mathrm{CH}^{\mathrm{p}} /$, Janko Masár $s$ Trnovej $/ \underline{\mathrm{K}}+$ $\mathrm{CH}^{\mathrm{z}}+\mathrm{MD}=\mathrm{CH}^{\mathrm{p}} /$, Miško Klimáčkéch z Dúbravi $/ \underline{\mathrm{K}}+\mathrm{RM}=\mathrm{P}+\mathrm{MD}=\mathrm{CH}^{\mathrm{p}} /$, Miro Valentéch ze Zátački $/ \underline{\mathrm{K}}+\mathrm{RM}=\mathrm{P}+\mathrm{MD}=\mathrm{CH}^{\mathrm{p}}$, Jano Beno s Trnovej $/ \underline{\mathrm{K}}$ $+\mathrm{P}=\mathrm{RMD}+\mathrm{MD}=\mathrm{CH}^{\mathrm{p}} /$, Palo Ilušák s Trnovej $/ \underline{\mathrm{K}}+\mathrm{P}=\mathrm{RMD}+\mathrm{MD}=\mathrm{CH}^{\mathrm{p}} /$, Dušan Mednanski z Dúbravi $/ \mathrm{K}+<\mathrm{P}>=\mathrm{RMD}+\mathrm{MD}=\mathrm{CH}^{\mathrm{p}} /$, Ze Zátački Šimún Valentéch $/ \mathrm{MD}=\mathrm{CH}^{\mathrm{p}}+<\mathrm{K}>+\mathrm{RM}=\mathrm{P} /$, Jano Gento Klimáčeks Trnovej $/ \underline{\mathrm{K}}+$ $\mathrm{CH}^{\mathrm{n}} / \mathrm{MD}+\mathrm{P}=\mathrm{MD}+\mathrm{MD}=\mathrm{CH}^{\mathrm{p}} /$, Janko Stacho Masár $s$ Trnovej $/ \underline{\mathrm{K}}+\mathrm{P}=\mathrm{RMD}$ $+\mathrm{CH}^{\mathrm{z}}+\mathrm{MD}=\mathrm{CH} \mathrm{p} /$, Šmún na Dúbrave $/<\mathrm{K}>+\mathrm{MD}=\mathrm{CH} /$, Janko Stacho Masár na Trnovej $/ \underline{\mathrm{K}}+\mathrm{P}=\mathrm{RMD}+\mathrm{CH}^{\mathrm{z}}+\mathrm{MD}=\mathrm{CH}^{\mathrm{p}} /$, Milka z Dúbravy Ze školi $/ \underline{\mathrm{K}}$ $+\mathrm{MD}=\mathrm{CH}^{\mathrm{p}}+\mathrm{MD}=\mathrm{CH}^{\mathrm{p}} /$, Milka s Trnovej $/ \underline{\mathrm{K}}+\mathrm{MD}=\mathrm{CH}^{\mathrm{p}} /$, Róska s Trnovej $/ \underline{\mathrm{K}}+\mathrm{MD}=\mathrm{CH}^{\mathrm{p}} /$, Mariša z Úhora $/ \underline{\mathrm{K}}+\mathrm{MD}=\mathrm{CH}^{\mathrm{p}} /$, Vaščanka $z$ Dúbravi $/ \mathrm{CH}^{\mathrm{p}}$ $+\mathrm{MD}=\mathrm{CH}^{\mathrm{p}} /$, Anička Šimúnkova ze Zátački $/ \underline{\mathrm{K}}+\langle\underline{\mathrm{K}}\rangle_{3}+\mathrm{MD}=\mathrm{CH}^{\mathrm{p}} /$, Milki z Jami céra $/\left(\underline{\mathrm{K}}+\mathrm{MD}=\mathrm{CH}^{\mathrm{p}}\right)_{11}+\mathrm{A} /$, Milka $z$ Dúbravy Ze školi $/ \underline{\mathrm{K}}+\mathrm{MD}=\mathrm{CH}^{\mathrm{p}}$ $+\mathrm{MD}=\mathrm{CH}^{\mathrm{p}} /$, Vlasta Valentová ze Zátački $/ \mathrm{K}+\mathrm{P}_{3}=\mathrm{RMD}+\mathrm{MD}=\mathrm{CH}^{\mathrm{p}} /$, Lubo Gurášni s Papierne $/ \underline{\mathrm{K}}+\mathrm{CH}_{1}{ }_{1}+\mathrm{MD}=\mathrm{CH}^{\mathrm{p}}:<\mathrm{MD}>/$, Jana Stančikéch s Trnovej $/ \mathrm{K}+\mathrm{RM}=\mathrm{P}+\mathrm{MD}=\mathrm{CH}^{\mathrm{p}} /$, Kačka Valentová (ze Zátački) $/ \underline{\mathrm{K}}+\mathrm{P}_{1}=\mathrm{RMD}+$ ${ }^{0} \mathrm{MD}=\mathrm{CH}^{\mathrm{p}} /$, Spopot chodníka Palo Durec Lenin $/<\mathrm{MD}>=\mathrm{CH}^{\mathrm{p}}+\underline{\mathrm{K}}+\mathrm{P}_{1}+\mathrm{CH}^{\mathrm{v}} /$ $\mathrm{MD} /$, Buno Imrich Spot skalki, pani Bunová Imrichova Spot skalki /A - $\mathrm{P}_{3}+\mathrm{K}_{3}$ $=\mathrm{RMD}+\mathrm{MD}=\mathrm{CH}^{\mathrm{p}} /$, Palo Múdrich s Pálenikech rátku $/(\underline{\mathrm{K}}+\mathrm{RM}=\mathrm{P}):<\mathrm{MD}>$ $+\mathrm{MD}=\mathrm{CH}^{\mathrm{p}} /$, Dušan Mednanskí z Močára $/ \mathrm{K}+<\mathrm{P}>+\mathrm{MD}=\mathrm{CH}^{\mathrm{p}} /$, Peter Durec s Polomi $/ \mathrm{K}+\mathrm{P}+\mathrm{MD}=\mathrm{CH}^{\mathrm{p}} /$, Pašmička spod Lipovca $/ \mathrm{RM}_{3}=\mathrm{P}+\mathrm{MD}=\mathrm{CH}^{\mathrm{p}} /$, $Z$ Bjelčikéch dolini Ruda Kubánka manželka $/ \mathrm{MD}=\mathrm{CH}^{\mathrm{p}}+(\underline{\mathrm{K}}+\mathrm{P}=\mathrm{RMD})_{3}+$ $\mathrm{A} /$, Vaščanka z Dúbravi $\left./ \mathrm{CH}^{\mathrm{p}}+\mathrm{MD}=\mathrm{CH}^{\mathrm{p}} /\right)$,

e) predložkou za a apelatívom (Jano Raškéch Za kultutákom $/ \mathrm{K}+\mathrm{RM}_{1}=$ $<\mathrm{MD}>+\mathrm{MD}=\mathrm{CH}^{\mathrm{p}} /$, Jano Durec Za kulturákom $/ \underline{\mathrm{K}}+\mathrm{P}_{1}+\mathrm{MD}=\mathrm{CH}^{\mathrm{p}} /$, Jano Raškéch Durec Za kulturákom $\left./ \underline{\mathrm{K}}+\mathrm{RM}_{1}=<\mathrm{MD}>+\mathrm{P}_{1}+\mathrm{MD}=\mathrm{CH}^{\mathrm{p}} /\right)$,

f) predložkou od a pomenovaním menšej osady (Jano Ťaški s Černochovho Vrchu ot Ťaškich $/ \underline{\mathrm{K}}+\mathrm{P}_{1}=\mathrm{RMD}+\mathrm{CH}^{\mathrm{p}}+\mathrm{MD}=\mathrm{P} /, \mathrm{U}$ Ťažkých je pomenovanie menšej osady, patriacej pod Černochov Vrch), 
g) predložkou od a apelatívom (Andrejka Stančikéch Od zbrojnice z Drgonéch dolini, Andrejka Stančkéch Od opchodu z Drgonéch dolini, Eva Vašková Ze školi z Durcéch dolini, Janko Z mlina z Durcéch dolini),

h) predložkou, kolektívnym posesívom antroponyma bývalého majitel'a alebo privlastňovacím prídavným menom odvodeným príponou -ov od substantíva mužského rodu a apelatívom (Kupka na Vdovjakech chalupe $/ \mathrm{P}+\mathrm{MD}_{21}$, Tichá na Hučekovom dome $\left./ \mathrm{P}_{3}+\mathrm{MD}_{21} /\right)$,

i) predložkou a antroponymom podl'a manželky (s antropobázou jej dievčenského priezviska) (Jano Pribiš u Krúpo $\underline{\mathrm{u}} / \underline{\mathrm{K}}+\mathrm{P}=<\mathrm{RMD}>+\mathrm{MD}_{33}=\mathrm{P} /$, ide o živé meno muža, ktorý sa prist'ahoval do domu manželky),

j) predložkou a antroponymom, ktoré vychádza z antropobázy rodného priezviska matky, je v tvare genitívu plurálu substantíva mužského rodu, obsahuje predložku od (Anna od Otiepkov $/ \mathrm{K}+\mathrm{MD}_{11}=\mathrm{P} /$, Anča od Otiepkov $/ \underline{\mathrm{K}}+\mathrm{MD}_{11}=\mathrm{P} /$,

k) meno domu s príbuzenskou motiváciou podl'a starého otca v podobe apelatíva (Vichlopnech vnuk Ze stanici Marek $/<\underline{\mathrm{P}}_{4}>+\mathrm{A}+\mathrm{MD}_{4}=\mathrm{CH}^{\mathrm{p}}+\mathrm{K} /$, Vichlopnech vnuk Ze stanici Rasto $/<\underline{\mathrm{P}}_{4}>+\mathrm{A}+\mathrm{MD}_{4}=\mathrm{CH}^{\mathrm{p}}+\underline{\mathrm{K}} /$,

1) predložkou a živým menom družky, pozostávajúcim z úradnej podoby rodného mena a rodinného mena podl’a predchádzajúceho manžela, ktoré vychádza z antropobázy jeho priezviska a ktoré má tvar kolektívneho posesíva (Gustáv Šupák (f Košćáléch doline) (u Anni Michalcéch) $/ \mathrm{K}+(\mathrm{RM}: \mathrm{MD})+{ }^{0} \mathrm{CH}^{\mathrm{p}}+{ }^{0}[\mathrm{MD}=$ $\left.\left(\mathrm{K}+\mathrm{RM}_{[3]}=\mathrm{P}\right)_{33}\right] /$, tento funkčný člen, meno domu, sme zaznamenali v Papradi, funguje fakultatívne a vyjadruje miesto, kde pomenovaná osoba býva).

$\mathrm{V}$ jednom živom mene je ukryté i hydronymum, názov vodnej nádrže, ako súčast' názvu hrádze: Peter Milata Z hrádze Dubníg dva.

Meno domu sa nachádza $\mathrm{v}$ genitíve plurálu substantíva mužského rodu, ked' obsahuje predložku ot (vyjadruje význam smerový), alebo v lokáli singuláru substantíva mužského rodu, ked' má predložku na (vyjadruje význam miestny). Vo význame miestnom sa však najčastejšie použiva tvar genitívu plurálu s predložkou $u$. Doložený máme aj tvar genitívu singuláru s predložkou $u$, pozostávajúci z rodného mena a rodinného mena $\mathrm{s}$ antropobázou priezviska (kolektívneho posesíva z priezviska) (u Anni Michalcéch). Pri $\mathrm{MD}=\mathrm{CHp}$ sa uplatňuje aj predložka $z$ (zo) a jej vokalizovaná nárečová podoba ze a funkčný člen je v tvare genitívu (singuláru mužského alebo ženského rodu alebo plurálu mužského rodu). Okrem toho sa pri $\mathrm{MD}=\mathrm{CHp}$ uplatňuje predložka $n a$, pri ktorej je FČ v lokáli singuláru ženského rodu, a predložka spopod, pri ktorej je FČ v genitíve singuláru mužského rodu. Pri $\mathrm{MD}=\mathrm{CHp}$ meno domu spravidla vyjadruje polohu bydliska (názov časti osady alebo názov, ktorý možno považovat' za chotárny názov), obsahuje aj názov budovy bydliska. Doloženú máme i predložku spod, ktorá sa viaže na genitív.

Meno domu podl'a predchádzajúceho majitel’a je v lokáli singuláru posesívneho adjektíva a substantíva stredného rodu a spája sa s predložkou na.

Meno domu sa okrem apelatívneho člena spájalo so všetkými ostatnými funkčnými členmi ( $\mathrm{K}, \mathrm{P}, \mathrm{CH}, \mathrm{RM})$. Hoci v materiáli nie je doložené, môže sa spájat's apelatívnym členom (napr. *ujo z Dúbravy, *teta u Mikulcov). 
Meno domu ako samostatné pomenovanie dvora, gruntu a jeho obyvatel'ov sa v skúmanej lokalite spája vo význame miestnom: 1) s predložkou $u$ pri spojení s genitívom (U Vagačov, U Áronéch); 2) s predložkou na pri spojení s lokálom ( $N a$ jágerni, Na mline, Na Barine, Na Úhori, Na škole, Na Brezovke); 3) s predložkou pri v spojení s lokálom (Pri opchode, Dolni Súś pri starom opchode); 4) s predložkou oproti v spojení s datívom (Súž oproti zbrojnice); 5) s predložkou vella (spis. vedl'a) pri spojení s genitívom (Vella zbrojnice); 6) s predložkou za pri spojení s inštrumentálom (Za potokom) a 7) s predložkou pod pri spojení s inštrumentálom (Pot chodníkom za kulturákom, Pod lomami).

Vo význame smerovom sa v datíve vyskytuje bezpredložkové spojenie (Žákovicom, Bjelčíkom, Gavačovom, Hluchím), môže byt' k nemu pridaná predložka $k$ (G Áronom), objavujú sa aj spojenia s genitívom s predložkou do (Do Bjesikov), spojenie v akuzatíve (Na Bjelčíkech mlin, Na jamu, Na smetlisko) a v inštrumentáli (Za Čičmanskím, Za Jarom Richtárech). Ojedinele sa dom pomenúva priamo nominatívom (Hluchich mlin, Starí mlin) alebo spojením s nominatívom apelatíva dom (Po Janovi Pavlovich dom).

Meno domu môže byt' odvodené z rodného (krstného) mena majitel'a, z úradnej alebo formálne adaptovanej podoby priezviska, z rodinného mena, ktorého základ nie je zhodný s priezviskom, z mena predchádzajúceho majitel’a (priezviska, prezývky, rodinného mena; s predložkou na - Na Nemcéch, jedenkrát sme zachytili prípad s predložkou po - v Topoleckej podl'a prezývky bývalého majitel'a Po Apatikárovi), zo živého osobného mena obyvatel'a (Leninovi, Milanovi Bukovčanovi, Vjere Bukovčanéch) a podl'a miesta polohy.

Nárečovým prvkom je neprítomnost' dvohlásky ia (z Močára, rátku - nárečovým je i samotné slovo rádek v tvare nominatívu singuláru, kde je za tvrdý jer striednica $e$ miesto $o$ ), zakončenie substantíva ženského rodu vzoru ulica v genitíve singuláru miesto $e$ na $i$ (Ze stanici). Miesto $\check{n}$ sa vyslovuje tvrdé $n$. Spisovná podoba od Otiepkovcov sa nahrádza podobou od Otiepkov. Miesto pomenovania kultúrny dom tu stojí nespisovné hovorové univerbizované slovo kulturák.

Pri mene domu ako samostatnom živom mene I. Valentová [2009: 103-105] zaznamenáva rôzne (bohaté) jazykové formy: 1. s predložkou do, 2. s predložkou $k(k u), 3$. s predložkou na, 4. bezpredložkové meno domu.

Medzi menami domov a názvami kopaníc stoja mená - názvy skupiny niekol'kých domov (Ježéch dvori, V Ježéch dvoroch, Vjeden, Brezovka, Sichrovec, Járki, Amerika, Austrália).

\section{Toponymá v živých menách a lexika}

Osada Černochov Vrch je osada na kopci, vrchu, pomenovaná podl'a jej obyvatel'ov, antroponymum Černoch = tmavý človek. Durcova dolina, Drgoňova dolina, Koštialova dolina sú osady v doline pomenované podl'a ich obyvatel'ov. Ná- 
zov osady Paprad' je motivovaný výskytom paprade, názov osady Topolecká zase výskytom topol’ov. Súš predstavuje suché miesto, Trávniky trávnaté miesto. Osada U Samkov dostala svoje pomenovanie podl'a obyvatel'ov (priezvisko Samko $<$ hypokoristická podoba rodného mena Samko < rodné meno Samuel). Názov osady Lazy pochádza z apelatíva laz, ktorý podl’a V. Machka [1968: 322] predstavuje pole alebo lúku získanú zničením lesa. J. Dorul’a [1993: 86] spresňuje významy slov kopanice a lazy. Lazy sa podl'a neho na rozdiel od kopaníc neobrábali, neorali a využívali sa ako lúky. Osada Jazviny predstavuje miesto v úžlaabine, tak ako to vyplýva z apelatívneho významu slov jazva, jazvina, ,úžlabina“. Názvami so slovom jazvina sú pomenované najmä svahy, úbočia zbrázdené jarkami a úžlabinami [Majtán 1996: 36]. Názov samoty Nárcie súvisí so staroslovienskym $r 7 t 7$, ktorého významy sú podla J. Stanislava napr. „vrchol“, „chlm, pahorok, návršie“ [Majtán 1996: 52]. Názov osady Hlavina vyjadruje charakter terénu. Podl’a F. Cuř́na [1967: 131] pri výklade treba vychádzat' z významu ,zaoblená vyvýšenina, svah, príp. kopec. V Čechách sa názvy Hlaviny vyskytujú v oblastiach so zvleným, kopcovitým, nie vel'mi vysokým terénom [Cuř́n 1967: 131]. Pomenovania domu ako označenie objektov s lexémou rádekv Papradi máme doložené v podobách Pálenikech rádek, Na Páleníkéch rátku. Ide o skupinu domov, ktorá je pomenovaná prostredníctvom kolektívneho privlastnenia. Predpokladáme, že čast' Pálenikech (kolektívne posesívum) bolo rodinným menom, ktoré vzniklo z individuálnej charakteristiky alebo priezviska alebo bolo starým rodinným menom. Individuálna charakteristika (najpravdepobnejšie podla povolania alebo záujmu) vychádzala z apelatíva páleník, ktoré označovalo osobu, ktorá „pálila“ (vo význame produkovala alkohol). Motiváciou vzniku prvotného propria bolo zrejme to, že sa pomenovaný venoval tejto činnosti. Funkčné členy meno domu u Strelcov a ot Strelcov, ktoré majú podobu genitívu plurálu a spájajú sa s predložkou $u$ alebo $o d$, súvisia s pomenovaním skupiny domov. Meno domu pôvodne vychádzalo z mena rodiny, ktoré podl'a miestnej l'udovej tradície vzniklo podl'a toho, že predkovia rodiny slúžili u strelcov v rakúsko-uhorskej armáde (l'udová etymológia, možno pravdivá). Toponymum Dúbrava bolo motivované dubovým porastom, Brezovka brezovým porastom, Lipovec lipovým porastom, Poloma predstavovala polámané stromy, les, Močár močaristé miesto. Lokality Amerika, Austrália volajú podl'a ich odlahlosti, vzdialenosti. Názov Sichrovec pravdepodobne súvisí s významom slova sychravý, ,,vlhký a chladný“. Názov Vjeden môže znamenat' „exkluzívnost"“ miesta, kde sa skupina domov nachádza.

\section{Antroponymá v toponymách}

V staroturianskej oblasti je aj pomerne hojný výskyt názvov odvodených z priezvisk pôvodných majitel'ov chotárov (Veteš, Ježo, Klimo, Košt'ál, Mikulec a pod.): Mihálovec - les, Mičovka - lúka, Vetešov járek - hora, Ježová - hora, Klimová - lúka (hora), Koštálech dolina (čast' Paprade) = Koštálech vrški, U Mikulcov, U Škriečkov (osady). 


\title{
Záver
}

V menách domov sa často odzrkadl'uje vzt’ah k obyvatel'om. Mená domov bývajú motivované menami predošlých alebo súčasných obyvatel’ov alebo sú motivované ich polohou, ked' do živého mena vstupuje chotárny názov. Osamostatnením funkčného člena živého osobného mena meno domu sa meno domu považuje za toponymum.

Ojkonymá a anojkonymá sú integrálnou súčastou funkčných členov živých osobných mien. Báza ojkoným a anojkoným sa v živých osobných menách objavuje $\mathrm{v}$ podobe individuálnej charakteristiky podl'a pôvodu a bydliska a v mene domu.

\section{Bibliografia}

Blanár Vincent, 1996, Teória vlastného mena, Bratislava.

Blanár Vincent, Matejčík Ján, 1978, Živé osobné mená na strednom Slovensku (1. diel). Designácia osobného mena, Bratislava.

Cuř́n František, 1967, Studie z historické dialektologie a toponomastiky Čech, Praha.

Dorul'a Ján, 1993, Tri kapitoly zo života slov, Bratislava.

Krasnovská Elena, 1976, Kartografovanie mien do domu, [in:] Michal Blicha, Milan Majtán (eds.), Zborník materiálov z V. zasadania Medzinárodnej komisie pre slovanskú onomastiku a V. slovenskej onomastickej konferencie (3.-7. mája 1972 v Prešove), Bratislava, 43-46.

Kriššáková Júlia, 1976, Živé mená s toponymickým základom v goralskej oblasti na Spiši, [in:] Milan Majtán (ed.), Zborník materiálov zo VI. slovenskej onomastickej konferencie (4.-6. apríla 1974 v Nitre), Bratislava, 61-65.

Machek Václav, 1968, Etymologický slovník jazyka českého, Praha.

Majtán Milan, 1996, Z lexiky slovenskej toponymie, Bratislava.

Valentová Iveta, 2009, Živé osobné mená v hornonitrianskej oblasti, Jazykovedné štúdie 27, Bratislava.

\author{
Miroslav Kazik
}

\section{Toponyms in living (unofficial) personal names}

\author{
(Summary)
}

Toponyms in living names could serve as a foundation for creating a citizen name which is part of living name. However toponyms themselves can step into living names. Oikonyms and anoikonyms are the integral part of functional articles of living personal names. The basis of oikonyms and anoikonyms occurs in the living personal names in the form of individual characteristic according to origin and residence and in the name of house. The essence of living names comes from field research in the solitary-cottages area in Stará Turá region.

Słowa kluczowe: żywe imiona osobowe, charakterystyka indywidualna, nazwa domu, Słowacja Zachodnia.

Keywords: living (unofficial) personal names, individual characteristic, name of house, western Slovakia. 